\title{
Physical characteristics of eddible film from carrageenan with liquid smoke addition
}

\author{
Karakteristik fisik edible film dari karaginan dengan penambahan asap cair \\ Tomy Moga $^{1}$, Roike I. Montotolalu ${ }^{2}$, Sigfried Berhimpon $^{2}$, and Feny Mentang ${ }^{2}$ \\ ${ }^{1}$ Program Studi Ilmu Perairan, Program Pascasarjana Universitas Sam Ratulangi. Jln. Kampus Unsrat Kleak, \\ Manado 95115, Sulawesi Utara, Indonesia \\ ${ }^{2}$ Fakultas Perikanan dan Ilmu Kelautan, Universitas Sam Ratulangi. Jl. Kampus Unsrat Bahu, Manado 95115, \\ Sulawesi Utara, Indonesia \\ *E-mail: tomy_moga@yahoo.com
}

\begin{abstract}
Packaging materials food which are multifunctional and safe for consumers and the environment is the focus of today's food packaging studies. Edible films that are made from carrageenan is one form of primary packaging for food. The physical properties of the packaging has become an important component to be considered in choosing packaging. The study was conducted to determine the effect of carrageenan concentration on the physical properties of solubility, thickness, tensile strength, percentage of elongation and water vapor transmission rate. The result showed that edible film processed from carrageenan with different concentrations have different physical properties. The higher the concentration of carrageenan used in the manufacture of edible film, the stronger the solubility of the edible film, the stronger the attractiveness, and the thicker and more resistant. Vapor transmission rate is getting lower, or in other word the ability to withstand water is high.
\end{abstract}

Keywords: carrageenan; edible film; food precessing.

Abstrak: Kemasan bahan pangan yang multifungsi dan aman bagi konsumen dan lingkungan menjadi fokus kajian kemasan bahan pangan saat ini. Edible film dari bahan karaginan merupakan salah satu bentuk kemasan primer bagi bahan pangan. Sifat fisik kemasan menjadi komponen penting yang dipertimbangkan dalam memilih kemasan. Penelitian ini dilakukan untuk mengetahui pengaruh konsentrasi karaginan terhadap sifat fisik kelarutan, ketebalan, kuat tarik, persentasi perpanjangan putus dan laju transmisi uap air. Hasilnya diperoleh edible film yang diproses dari karaginan dengan konsentrasi yang berbeda memiliki sifat fisik yang berbeda. Semakin tinggi konsentrasi karaginan yang digunakan di dalam pembuatan edible film, maka edible film yang dihasilkan semakin tinggi kelarutannya, semakin kuat daya tariknya, semakin tebal dan semakin tahan serta laju transmisi uapnya makin rendah atau kemampuan menahan airnya tinggi.

Kata-kata kunci: karaginan; edible film; pengolahan makanan.

\section{PENDAHULUAN}

Akhir-akhir ini bahan kemasan yang berasal dari polimer petrokimia atau lebih dikenal dengan plastik, merupakan bahan kemasan yang paling banyak digunakan. Hal ini disebabkan karena beberapa keunggulan plastik, seperti fleksibel, mudah dibentuk, transparan, tidak mudah pecah, dan harganya yang relatif murah. Sedangkan kelemahan polimer plastik, yakni tidak tahan panas dan dapat menyebabkan kontaminasi melalui transmisi monomernya ke dalam bahan yang dikemas. Kelemahan lain dari plastik adalah sifatnya yang tidak dapat dihancurkan secara alami (non-biodegradable) sehingga menyebabkan beban bagi lingkungan khususnya pada negara-negara yang tidak melakukan daur ulang (recycling).
Seiring dengan kesadaran manusia akan masalah ini, maka dikembangkanlah jenis kemasan dari bahan organik yang terbarukan (renewable) dan ekonomis. Salah satu jenis kemasan yang bersifat ramah lingkungan adalah kemasan edible film (edible packaging). Keuntungan dari edible packaging adalah dapat melindungi produk pangan, penampakan asli produk dapat dipertahankan, dan dapat langsung dimakan serta aman bagi lingkungan (Kinzel, 1992). Lapisan tipis edible film yang dibentuk pada permukaan atau di antara komponen bahan pangan dapat mencegah penurunan mutu dari produk, yaitu dengan bertindak sebagai barrier untuk mengendalikan transfer uap air, pengambilan oksigen, kehilangan komponen volatil dan terlarut atau transfer lipid. Edible film memiliki potensi 
untuk mengurangi kompleksitas kemasan, limbah, dan biaya (Melia, 1997).

Edible film dapat dibuat dari tiga jenis bahan penyusun yang berbeda yaitu hidrokoloid, lipid, dan komposit dari keduanya (Donhowe and Fennema, 1994). Beberapa jenis hidrokoloid yang dapat dijadikan bahan pembuat edible adalah protein (gelatin, kasein, protein kedelai, protein jagung dan gluten gandum) dan karbohidrat (pati, alginat, pektin, gum arab dan modifikasi karbohidrat lainnya). Sedangkan lipid yang digunakan adalah lilin/wax, gliserol, dan asam lemak.

Hidrokoloid karaginan potensial untuk dibuat edible film, karena sifatnya yang kaku dan elastis serta dapat dimakan dan dapat diperbaharui (Suryaningrum and Basmal, 2005). Edible film dari karaginan dapat diformulasikan dengan selulosa dan derivatnya sebagai bahan penguat, plasticizer sebagai bahan pelentur dan karbohidrat sebagai bahan pengisi (Suryaningrum and Basmal, 2005).

Penggunaan asap cair dalam pengolahan pangan dapat memperpanjang masa simpan produk dengan mencegah kerusakan akibat aktivitas bakteri pembusuk dan patogen. Senyawa yang mendukung sifat antibakteri dalam destilat asap cair adalah senyawa fenol dan asam (Girarrd, 1992). Senyawa fenol dapat menghambat pertumbuhan populasi bakteri dengan memperpanjang fase lag secara proporsional di dalam produk. Sedangkan kecepatan pertumbuhan dalam fase eksponensial tetap tidak berubah kecuali konsentrasi fenol yang tinggi. Fraksi fenol yang mampu menghambat pertumbuhan bakteri adalah fenol dengan titik didih rendah (Barylko-Pikeilna,1979). Senyawa kimia yang dapat diidentifikasi dari hasil pengasapan jumlahnya lebih dari 200 jenis. Secara umum, senyawa yang ada pada asap kayu adalah karbonil, asam organik, fenol, basa organik, alkohol, hidrokarbon aromatik, dan gas-gas seperti $\mathrm{CO}_{2}, \mathrm{CO}$, $\mathrm{O}_{2}, \mathrm{~N}_{2}$ dan $\mathrm{N}_{2} \mathrm{O}$. Kompenen asap tersebut berfungsi sebagai bakterisidal, antioksidan, serta pembentuk flavor asap dan warna (Utomo et al., 2009).

Permasalahan pembuatan edible film dari bahan biopolymer adalah perbandingan antara konsentrasi bahan utama dengan plastisier dan bahan tambahan lainnya guna mendapatkan edible film yang tipis, mudah larut, memiliki laju transmisi uap air yang rendah, kuat tariknya tinggi, persentase pemanjangan tinggi dan persentase putus rendah. Karena itu dibutuhkan kajian untuk mendapatkan konsentrasi karaginan yang memunkingkan bagi pembuatan edible film dimaksud. Adapun tujuan dari penelitian ini adalah untuk menentukan karakteristik fisik edible film yang diproses dengan konsentrasi karaginan yang berbeda.

\section{MATERIAL DAN METODA}

\section{Tempat, Waktu, dan Bahan penelitian}

Penelitian ini dilakasanakan pada bulan Februari 2014 sampai Oktober 2014; di Laboratorium Teknologi Penanganan dan Pengolahan Hasil Perikanan, Fakultas Perikanan dan Ilmu Kelautan, Universitas Sam Ratulangi, Manado, dan pengujian fisik edible film dilaksanakan di Laboratorium Pengujian Balai Besar Kulit, Karet, dan Plastik, Yogjakarta.

Bahan yang digunakan dalam penelitian ini adalah karaginan (kappa karaginan), asap cair yang dibuat dari tempurung kelapa, pati sagu, aquades, $\mathrm{NaOH}$, lilin lebah, dan gliserol. Alat yang digunakan yaitu ember, baskom, pisau, telenan, mistar, oven, pemanas, timbangan analitik, blender, gelas ukur, erlenmeyer, corong pisah, pipet, gelas piala, hot plate stirer, termometer, $\mathrm{pH}$ meter, water vapour transmission rate tester, tensyl strenght tester, digital caliper. Sementara itu, pengeringan film menggunakan lemari pengering.

\section{Rancangan Percobaan}

Percobaan ini didesain menggunakan Rancangan Acak Lengkap (RAL) dengan lima perlakuan konsentrasi karaginan, yakni A: $1.5 \%$, B: $2.0 \%$, C: $2.5 \%$, D: $3.0 \%$, dan E: $3.5 \%$. Selanjutnya, masing-masing perlakuan diulang sebanyak dua kali sehingga diperoleh 10 unit percobaan. Parameter yang diukur untuk mngetahui karakteristik fisik edible film dari bahan karaginan ini adalah ketebalan, kelarutan, kuat tarik, persen pemanjangan, water vapour transmition rate (WVTR). Data yang diperoleh dianalisis menggunakan Analisis Ragam dan dilanjutkan dengan Uji Jarak Berganda Duncan.

Pembuatan edible film meliputi; tepung karaginan dilarutkan dalam air sesuai konsentrasi yang akan dicobakan, yakni $1.5 \%, 2.0 \%, 2.5 \%$, $3.0 \%$, dan $3.5 \% \mathrm{~b} / \mathrm{v}$ dan dipanaskan pada stiring hotplate pada suhu $70^{\circ} \mathrm{C}$ sambil diaduk dengan homogenizer. Selanjutnya, ditambahkan asap cair $0.8 \% \mathrm{v} / \mathrm{v}$ dan pemanasan serta pengadukan dilanjutkan selama 30 menit. Larutan didinginkan hingga mencapai suhu $50^{\circ} \mathrm{C}$, kemudian tambahkan gliserol sebagai plasticizer sebanyak $1 \% \mathrm{v} / \mathrm{v}$ dan pati sebanyak $5 \% \mathrm{~b} / \mathrm{v}$. Selanjutnya, dihomogenkan lalu dipanaskan lagi pada suhu $50{ }^{0} \mathrm{C}$ selama 5 menit. Kemudian, tambahkan asam lemak (lilin lebah) dan atur $\mathrm{pH}$ larutan hingga mencapai netral, sambil dipanaskan pada suhu $50^{\circ} \mathrm{C}$ dan diaduk dengan homogenizer. Larutan selanjutnya dituang pada cetakan akrilik $20 \times 20 \mathrm{~cm}$ dengan ketebalan 2 $\mathrm{mm}$. Biarkan pada udara terbuka selama 24 jam. 
kemudian keringkan pada lemari pengering selama 6 jam pada suhu $60^{\circ} \mathrm{C}$. Hasilnya diperoleh edible film yang tipis dan siap untuk diuji parameter fisiknya.

\section{HASIL DAN PEMBAHASAN}

\section{Kelarutan}

Data hasil pengukuran pengaruh konsentrasi karaginan terhadap kelarutan edible film menunjukkan, bahwa rata-rata nilai kelarutan berkisar 50$100 \%$. Hasil analisis keragaman menunjukkan, bahwa tidak ada pengaruh konsentrasi karaginan terhadap tingkat kelarutan edible film yang dihasilkan $(p>0,05)$. Secara keseluruhan rata-rata tingkat kelarutan edible film yang diproses dengan konsentrasi karaginan yang berbeda ditampilkan pada Gambar 1.

Gambar 1 menunjukkan, bahwa kelarutan tertinggi edible film diperoleh pada konsentrasi karagenan 3,0 \% dan 3,5\%. Hal ini mungkin disebabkan karena dalam air bagian hidrofobik dari asam-asam amino cenderung utuk berikatan satu dengan yang lainnya. Hal tersebut mencegah larutnya protein dalam air (Krochta and McHugh, 1994). Selain itu, kelarutan edible film dapat juga ditentukan oleh konsentrasi gliserol di mana semakin banyak gliserol (plastiziser) yang digunakan pada saat pembuatan, maka semakin larut edible film tersebut. Gliserol mempunyai sifat mudah larut dalam air, meningkatkan viskositas dalam larutan, mengikat air dan menurunkan aw (Lindsay, 1985). Namun dalam penelitian ini penggunaan gliserol sama untuk semua perlakuan sehingga mengakibatkan nilai kelarutan relative sama sehingga tidak berpengaruh nyata.

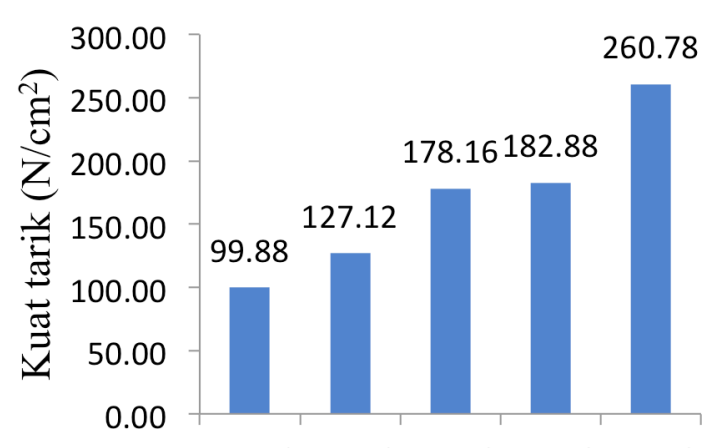

$1.50 \% 2.00 \% 2.50 \% 3.00 \% 3.50 \%$

Konsentrasi karaginan $(\% \mathrm{~b} / \mathrm{v})$

Gambar 1. Histogram nilai rata-rata rerata tingkat kelarutan edible film
Selain gliserol, dalam formulasi edible film digunakan juga pati dari sagu. Pati sagu mempunyai kecenderungan sulit larut dalam air. Kelarutan pati ini dipengaruhi oleh sifat kimiawi. Pati sagu merupakan polimer glukosa dengan ikatan 1,4 $\alpha$ glukosa; mengandung sekitar $27 \%$ amilosa dan $73 \%$ amilopektin (Bloomfield, 1996). Daya larut film sangat ditentukan oleh komposisi bahan dasar pembuatan film. Edible film berbahan dasar pati, tingkat kelarutannya dipengaruhi oleh ikatan gugus hidroksi pati. Makin lemah ikatan gugus hidroksil pati, maka makin tinggi kelarutan film. Edible film dengan daya larut yang tinggi menunjukkan film tersebut mudah dikonsumsi (Gontard et al., 1993). Selain itu, kelarutan edible film juga dipengaruhi oleh suhu (Rokhaniah, 2003).

\section{Kuat Tarik}

Kuat tarik diartikan sebagai besaran maksimum yang dibutuhkan untuk memutuskan spesimen bahan yang dibagi dengan luas penampang mula-mula, (Anonym, 2010). Hasil pengukuran kuat tarik edible film yang diproses dengan konsentrasi karaginan yang berbeda menunjukan, bahwa nilai kuat tarik berkisar 99,88260,78 N/cm2. Hasil Analisis Ragam menunjukkan, bahwa perlakuan konsentrasi karaginan berpengaruh sangat nyata $(p<0,01)$ terhadap nilai kuat tarik edible film. Secara keseluruhan, nilai rata-rata kuat tarik edible film yang dihasilkan ditampilkan pada Gambar 2.

Gambar 2 menunjukan, bahwa edible film dengan perlakuan 3,5\% memiliki kuat tarik yang lebih tinggi dibandingkan dengan perlakuan yang lainnya. Hal ini diduga karena sifat-sifat fungsional dari karaginan sebagai water binding, kelarutan, viskositas, pembentukan gel (Kinsella et al., 1985).

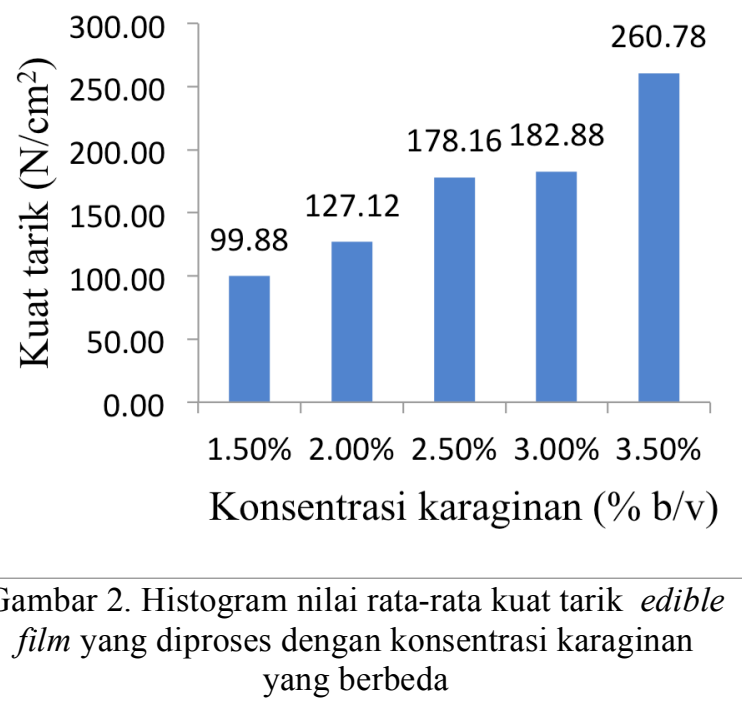


Menurut Fardiaz (1989), pembentukan gel merupakan suatu fenomena penggabungan atau pengikatan silang rantai-rantai polimer sehingga terbentuk suatu jala tiga dimensi bersambungan. Selanjutnya, jala ini menangkap atau mengimobilisasikan air di dalamnya dan membentuk struktur yang kuat dan kaku. Sifat pembentukan gel ini beragam dari satu jenis hidrokoloid ke jenis lain, tergantung pada jenisnya.

Nilai kuat tarik yang tinggi dapat mendukung kegunaan edible film sebagai kemasan. Edible film dengan kekuatan tarik yang tinggi akan mampu melindungi produk yang dikemasnya dari gangguan mekanis dengan baik (Supeni et al., 2015).

\section{Ketebalan}

Data hasil pengukuran pengaruh konsentrasi karaginan terhadap tingkat ketebalan edible film menunjukkan nilai kelarutan berkisar 120.13-161.34 $\mathrm{m} \mu$. Hasil analisis keragaman menunjukkan, bahwa perlakuan konsentrasi karaginan tidak memberikan pengaruh yang nyata $(p>0,05)$ terhadap tingkat ketebalan edible film. Secara lengkap, nilai rata-rata ketebalan edible film yang diproses dengan konsentrasi karaginan yang berbeda ditampilkan pada Gambar 3.

Gambar 3 menunjukkan, bahwa ketebalan edible film cenderung mengalami peningkatan dengan meningkatnya konsentrasi karaginan yang digunakan Kisaran nilai ketebalan di atas tidak jauh berbeda dengan hasil penelitian yang lainnya. Menurut Siswanti (2008), edible film dari komposit maizena glukomanan mempunyai ketebalan 0,16130,1828 mm. Kusumawati (2013) melaporkan, bahwa ketebalan edible film dari pati jagung dengan tambahan temu hitam berada pada kisaran 0,06-0.17 mm. Menurut Skurtys et al. (2011), ketebalan edible

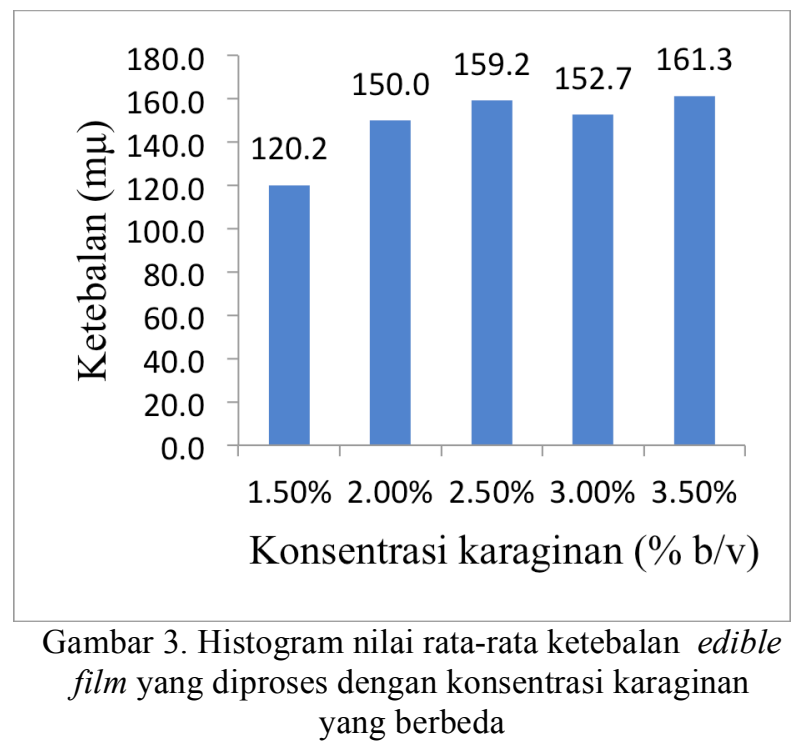

film biasanya kurang dari $0,25 \mathrm{~mm}$.

Semakin meningkat konsentrasi bahan yang digunakan akan menyebabkan peningkatan ketebalan film (Krochta and McHugh, 1994). Sedangkan menurut Harris (2001), peningkatan konsentrasi bahan yang digunakan akan meningkatkan total padatan yang terdapat dalam edible film setelah dikeringkan sehingga akan menghasilkan film yang semakin tebal. Apabila campuran edible film berisi komposisi yang maksimal dari bahan, maka akan didapatkan larutan yang sangat kental dan memilki ketebalan yang lebih dari pada komposisi yang lain (Prasetyaningrum et al., 2010). Ketebalan berhubungan dengan laju transmisi uap air serta kekuatan tarik dan elongasi. Semakin tebal edible film, maka sifatnya sebagai barrier akan semakin baik, tetapi dalam penggunaanya ketebalan edible film disesuaikan dengan produk yang dikemasnya (Kusumasmarawati, 2007). Edible film yang terlalu tebal juga dapat memberikan efek yang merugikan (Park et al., 1994)

Penelitian ini menggunakan plat dengan ketebalan yang relatif memiliki volume yang sama (20 cm x $20 \mathrm{~cm} \times 2 \mathrm{~mm}$ ). Sehingga di duga bahwa ketebalan yang meningkat dipengaruhi oleh konsentrasi bahan. Menurut Isnawati (2008), sifat fisik ketebalan edible film dipengaruhi oleh konsentrasi larutan dan penggunaan plat.

\section{Pemanjangan}

Persentase pemanjangan putus edible film didasarkan pada penambahan panjang pada saat bahan putus. Data pengukuran pengaruh konsentrasi karaginan terhadap kelarutan edible film menunjukkan, bahwa nilai rata-rata persentase pemanjangan putus berkisar 9.93-24.16 \%. Hasil Analisis

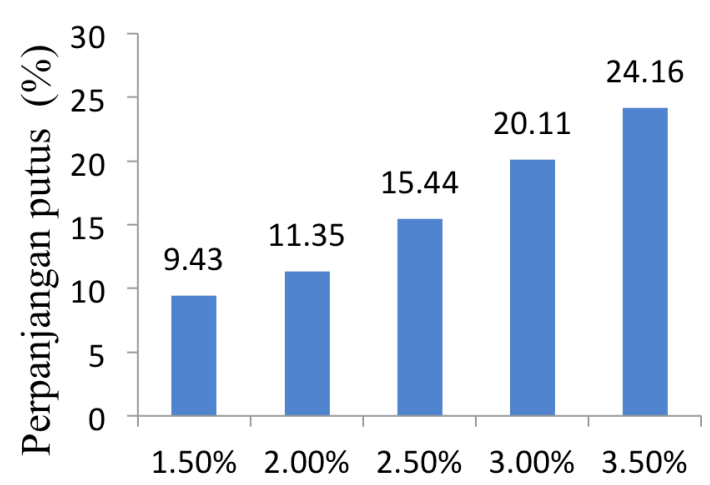

Konsentrasi karaginan $(\% \mathrm{~b} / \mathrm{v})$

Gambar 4. Histogram nilai rata-rata perpanjangan putus edible film yang diproses dengan konsentrasi karaginan yang berbeda 
Ragama menunjukkan, bahwa perlakuan karaginan dan konsentrasi tidak memberikan pengaruh yang nyata $(p<0,05)$. Secara keseluruhan, nilai rata-rata perpanjantan putus edible film ditampilkan pada Gambar 4.

Gambar 4 menunjukkan, bahwa perlakuan dengan konsentrasi karaginan yang tinggi (3.5\%) mempunyai persentase pemanjangan yang lebih panjang atau secara fisik lebih tahan. Hal ini diduga karena salah satu sifat dasar karaginan adalah pembentukan gel. Menurut Fardiaz (1989), gel mempunyai sifat seperti padatan, khususnya sifat elastis dan kekakuan. Proses pemanasan dengan suhu yang lebih tinggi dari suhu pembentukan gel akan mengakibatkan polimer karagenan dalam larutan menjadi random coil (acak). Bila suhu diturunkan, maka polimer akan membentuk struktur double helix (pilinan ganda); dan apabila penurunan suhu terus dilanjutkan polimer-polimer ini akan terikat silang secara kuat dan dengan makin bertambahnya bentuk heliks akan terbentuk agregat yang bertanggung jawab terhadap terbentuknya gel yang kuat. Jika diteruskan, maka akan terbentuk agregat. Selanjutnya akan terus gel lanjutan yang memungkinkan terjadinya proses mengerut sambil melepaskan air. Proses terakhir ini disebut sineresis.

Hasil penelitian serupa juga dilaporkan oleh Irianto et al. (2005), bahwa penggunaan konsentrasi karaginan yang semakin tinggi menyebabkan kemampuan mengikat air menjadi lebih baik sehingga menghasilkan matriks gel yang dapat meningkatkan persentase pemanjangan dan kekuatan tarik.

Pemanjangan edible film menunjukkan tingkat pemanjangan film pada saat ditarik sampai putus. Semakin besar nilai pemanjangan, maka semakin baik edible film, karena lebih elastis dan tidak mudah sobek. Persentase pemanjangan dikatakan baik, jika nilainya lebih dari $50 \%$; dan dikatakan rendah, jika nilainya kurang dari $10 \%$ (Krochta and Johnston, 1997).

\section{Laju Transmisi Uap Air}

Data hasil pengukuran pengaruh konsentrasi karaginan terhadap laju transmisi uap air edible film menunjukkan, bahwa nilai tertinggi diperoleh pada konsentrasi rendah $(1.5 \%)$, dan nilai terentah diperoleh pada konsentrasi $3.5 \%$ di mana semakin tinggi konsentrasi, maka laju transmisi makin lambat. Hasil Analisis Ragam menunjukkan, bahwa perlakuan konsentrasi karaginan tidak memberikan pengaruh yang nyata $(p>0,05)$. Profil nilai rata-rata laju transmisi uap air dimaksud ditampilkan pada Gambar 5.

Dari histogram di atas, nampak jelas terlihat, bahwa perlakuan dengan konsentrasi $2.5 \%$ mempunyai Laju Transmisi Uap Air yang tinggi; sedangkan yang terendah ada pada konsentrasi $3.5 \%$. Hal ini disebabkan oleh sifat dasar karaginan di mana mudah membentuk viskositas (kekentalan). Viskositas suatu hidrokoloid dipengaruhi oleh beberapa faktor, yaitu konsentrasi karagenan, temperatur, jenis karagenan, berat molekul, dan adanya molekul-molekul lain. Jika konsentrasi karagenan meningkat, maka viskositasnya akan meningkat secara logaritmik. Viskositas larutan karagenan disebabkan oleh sifat karagenan sebagai polielektrolit. Gaya tolakan (repulsion) antar muatan-muatan negatif sepanjang rantai polimer, yaitu gugus sulfat, mengakibatkan rantai molekul menegang. Karena sifat hidrofiliknya, polimer tersebut dikelilingi oleh molekul-molekul air yang

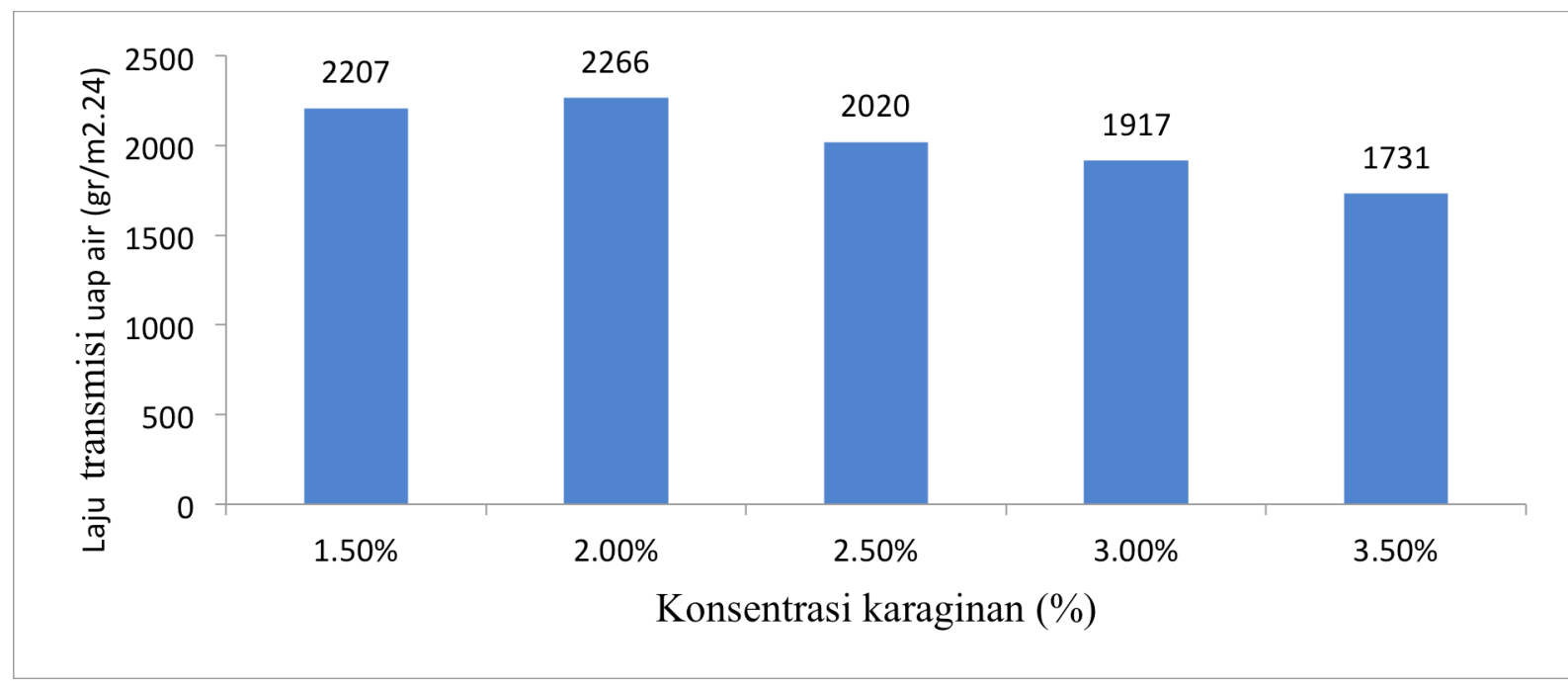

Gambar 5. Histogram nilai rata-rata laju transmisi uap air edible film yang diproses dengan konsentrasi karaginan yang berbeda 
termobilisasi, sehingga menyebabkan larutan karagenan bersifat kental (Fardiaz, 1989)

Ketebalan edible film mampu mempengaruhi laju transmisi uap air, karena menyebabkan laju transmisi semakin rendah seiring dengan meningkatnya ketebalan. Semakin kecil migrasi uap air yang terjadi pada produk yang dikemas oleh edible film, maka semakin bagus sifat edible film dalam menjaga umur simpan produk yang dikemas. Edible film relatif lebih tahan terhadap perpindahan oksigen dan karbondioksida, namun kurang tahan terhadap uap air (Pagella et al., 2002).

\section{KESIMPULAN}

Edible film yang diproses dari karaginan dengan konsentrasi yang berbeda memiliki sifat fisik yang berbeda. Semakin tinggi konsentrasi karaginan yang digunakan di dalam pembuatan edible film, maka semakin tingi kelarutannya, semakin kuat daya tariknya, semakin tebal, dan semakin tahan, serta laju transmisi uapnya makin rendah atau kemampuan menahan airnya tinggi

\section{REFERENCES}

ANONYM (2010) http://en.wikipedia.org/wiki/ Deformation_\%28engineering\%29, Wikipedia. Available at: http://en.wikipedia.org/wiki/ Defor-mation_\%28engineering\%29 (Accessed: 12 January 2016).

BARYLKO-PIKEILNA, N. (1979) Contribution Of Smoke Compound to Sensory, Bacterio-static and Antioxidative Effect in Smoked Food. Pure and Appl. Chem, 49(11), pp. 1667-1671.

BLOOMFIELD, M.M. (1996) Chemistry and Living Organism. 6th edn. Canada: John Willey \& Son Inc.

DONHOWE, G. and FENNEMA, O. (1994) Edible film and coating: Characteristic, formation, definitions and testing method. Lancester: Technomic. Publ. Co. Inc.

FARDIAZ, D. (1989) Buku dan Monograf Hidrokoloid. Laboratorium Kimia dan Biokimia Pangan. Bogor: Pusat Antar Universitas IPB.

GIRARRD, J.P. (1992) Smoking. 1st ed. New York: Ellis Horwood Ltd.

GONTARD, D., GUILBERT, S. and CUQ, J. (1993) Water and glycerol as plasticizers affect mechanical and water vapor barrier properties of an edible wheat gluten film. J. Food Sci., 58, pp. 206-211.

HARRIS, H. (2001) Kemungkinan penggunaan edible film dari tapioka untuk pengemas lempuk. Jurnal Pertanian Indonesia, 3(2), pp. 99-106.

IRIANTO, H.E., SUSANTI, A. and DARMAWAN, M.S. (2005) Pembuatan edible film dari komposit karaginan, tepung tapioka dan lilin lebah. Jurnal Penelitian Perikanan Indonesia, 11(2), pp. 93-101.

ISNAWATI, R. (2008) Kajian rasio mentega dan chitosan dalam edible film protein pollard terhadap sifat fisik telur ayam. Malang: Universitas Brawijaya.

KINSELLA, J.E., DAMODARAN, S. and GERMAN, B. (1985) Physicochemical and funtional properties of oilseed proteins with emphasis on soy proteins. New York: Academic Press, Inc.

KINZEL, B. (1992) Protein Rich Edible Coatings for Foods. Agricultural Research, pp. 20-21.

KROCHTA, J.M. and JOHNSTON, C.D.M. (1997) Edible an biodegradable films: challenges and opportunities. Food Technology, 51, pp. 61-74.

KROCHTA, J.M. and MCHUGH, T.H. (1994) Permeability properties of edible films. Lancester: Basel.

KUSUMASMARAWATI, A.D. (2007) Pembuatan Pati Garut Butirat Dan Aplikasinya Dalam pembuatan Edible Film. Yogyakarta: Universitas Gadjah Mada.

KUSUMAWATI (2013) Edible Film dari Pati Jagung yang Diinkorporasikan dengan Perasan Temu Hitam. Jurnal Pangan dan Agroindustri, 1(1), pp. 90-100.

LINDSAY, R. (1985) Food chemistry. New York: Marcel Dekker, Inc.

MELIA, S. (1997) Pengaruh Penambahan Beeswax dan Methylcellulose dengan Plasticizer Gliserol terhadap Karakteristik Edible Film Bungkil Kacang Kedelai. Bogor: Institut Pertanian Bogor.

PAGELLA, C., SPIGNO, G. and DE FAVERI, D.M. (2002) Characterization of starch based edible coatings. Trans I. Chem. E, 80, pp. 193198.

PARK, H.J., BUNN, J.M., WELLER, C.L., VERGANO, P.J. and TESTIN, R.F. (1994) Water vapor permeability and mechanical properties of grain proteinbased films as affected by mixtures of polyethylene glycol and glycerin plasticizers. Trans. ASAE, 37, pp. 1281-1285.

PRASETYANINGRUM, A., ROKHATI, N., KINASIH, D.N. and WARDANI, F.D.N. (2010) Karakterisasi Bioactive Edible Film dari Komposit Alginat dan Lilin Lebah Sebagai 
Moga et al.: Physical characteristics of edible film from carrageenan with liquid smoke addition ...

Bahan Pengemas Makanan Biodegradable. Seminar Rekayasa Kimia dan Proses, 02, pp. 1411-4216.

ROKHANIAH (2003) Isolasi dan Karakterisasi Pati Biji Nangka (Artocorpus heterophyllus Lamk) untuk Pembuatan Biodegradable Film. Yogyakarta: Universitas Gadjah Mada.

SISWANTI (2008) Karakterisasi Edible Film Komposit dari Glukomanan Umbi Iles Iles (Amorphopallus muelleri Blume) dan Maizena. Semarang: Universitas Negeri Semarang.

SKURTYS, et al. (2011) Food Hydrocoloid Edible Films and Coatings. Edited by Department of food Science and Technology. Chile: Universidad de Santiago de Chile.

SUPENI, G., AGUSTINA, A.C. and FITRINA, A.
(2015) Karakteristik sifat fisik dan mekanik penambahan kitosan pada edible film karagenan dan tapioca termodifikasi. ejournal.kemenperin. go.id.

SURYANINGRUM, Th.D. and BASMAL, J.N. (2005) Studi pembuatan edibel film dari karagenan. Jurnal Penelitian Perikanan Indonesia, 2(4), pp. 1-13.

UTOMO, B.S.B., FEBRIANI, R.A., PURWANINGSIH, S. and NURHAYATI, T. (2009) Pengaruh konsentrasi larutan asap cair terhadap mutu belut asap yang dihasilkan. Jurnal Pascapanen dan Bioteknologi, 4(1), pp. 49-58.

Received: 21 December 2017 Accepted: 20 February 2018 